\title{
Morpho-biochemical and immunohematologic features of calves infected with the agent of viral diarrhea
}

\author{
Aleksandr Belousov ${ }^{1, *}$, Evgenia Shilova ${ }^{1}$, Lyudmila $_{\text {Drozdova }}{ }^{1}$, and Antonina Poryvaeva ${ }^{1}$ \\ ${ }^{1}$ Ural Federal Agricultural Research Center of the Ural branch of the Russian Academy of Sciences, \\ 620142, 112a Belinskogo Street, Yekaterinburg, Russian Federation
}

\begin{abstract}
The key direction of scientific research is considered to be the study of the characteristics of the course and manifestation of the disease, as well as the determination of virulent properties of pathogens. Calves infected with the agent of viral diarrhea were chosen as a model for study of the infectious process. The study summarizes the pathogenetic mechanisms of development and expression of viral diarrhea. Clinical, biochemical, and immunehematologic features of the disease were specified. data on morphological changes in parenchymal organs of diseased animals were found. Changes in protein, lipid, mineral metabolism, and electrolyte balance indices associated with increased activity of lactate dehydrogenase are considered to be metabolic features of VD. Immunologic research showed a shift in the process of lymphocyte differentiation with activation of the b-cell link of immunity and a decline in the phagocytic index. Calves infected with VD revealed signs of structural immunodeficiency, which is morphologically confirmed by the decrease of most of the lymphoid follicles of the spleen. The lungs displayed signs of catarrhal and purulent bronchitis, manifested by hyperplasia of the bronchial epithelium, desquamation of the epithelium and accumulation of exudate in the bronchial lumen and peribronchial edema. Evidence of serous lymphadenitis were registered in the lymph nodes associated with reduction of subcapsular lymphoid follicles, both in the subcapsular and central sinuses. They were accompanied by the growth of connective tissue in the stroma of the organ.
\end{abstract}

\section{Introduction}

The issue of acute respiratory viral infections in cattle is still up-to-date for several decades. According to Russian and foreign researchers, seropositivity to VD of cattle is recorded in $60-80 \%$ of the livestock of productive animals in many countries of the world $[1,2,3,10,11]$. The contamination of livestock with the agent of VD of cattle in poor herds of

\footnotetext{
* Corresponding author:info@ urnivi.ru
} 
the Sverdlovsk region reaches from 6.7 to $16.7 \%$. [4]. The widespread and highly contagiousness of the disease is one of the most critical challenges of infectious diseases of farm animals $[5,7]$. The key direction is to identify epizootic virus strains, to study the peculiarities of the course and manifestation of the disease, and to identify the virulent properties of pathogens $[6,9]$. This may become the foundation for improving the means and methods of these diseases mmanagement.

For the development and implementation in veterinary practice of health measures to protect animals from viral diarrhea, an extensive and detailed analyses of the clinical, biochemical, and immunohematologic peculiarities of the disease manifestation is required.

The objective of this study was to examine the pathogenetic peculiarities of the course of the pathological process in calves suffering from viral diarrhea.

\section{Materials and methods}

This study was conducted at the Ural Federal Agricultural Research Center of the Ural branch of the Russian Academy of Sciences in the Department of Ecology and Non-Contagious Pathology and the Department of Monitoring and Predicting of Infectious Diseases under the State Assignment direction 160 of the program of fundamental scientific research of the state academies of sciences for 2013-2020. The topic was as follows: "Molecular biological and nanobiotechnological methods for creating new-generation biologics, technologies and techniques for their use to combat particularly dangerous infectious, parasitogenic and noninfectious diseases in animals.

Pilot researches were performed on the basis of breeding agricultural organizations specializing in dairy production in the Ural region . Object of study: calves aged 21-45 days $(\mathrm{n}=128)$.

A complex integral evaluation of animal characteristics was carried out: clinical status, biochemical profile, immunohematologic indices, infection with the agent of VD in cattle.

The clinical status of the animal was assessed by the commonly accepted method of I. G. Sharabrin (1988). Biochemical analysis of blood sera was conducted on an automatic biochemical analyzer Chem Well-2910 Combi by Awaveness Technology (USA) using standard reagent kits by Vital Diagnostics Spb (Russia) and DIALAB GmbH (Austria). The accuracy of the measurements is confirmed using tests suggested by the reagent manufacturers. Hematologic examinations were conducted using Abacus Junior Vet analyzer by Diatron (Austria) with the application of standard Diatron reagents (Austria). The immunological status of animals was assessed by the method of N. Smirnov and co-authors, 2007 [8]. Findings were recorded using a Micros microscope (Austria).

Problematic condition of the model agricultural enterprise was verified on the basis of detection of VD virus antigens in the blood serum of young cattle by the ELISA method using the BVDV Antigen Test Kit/Serum Plus (IDEXX Laboratories, Inc, USA). Seeding was performed in MDBK cell culture.

In the culture of MDBK cells from calves infected with VD, pieces of lungs, liver, kidneys, spleen, and lymph nodes were chosen for histological examination. The samples were prepared in accordance with standard, generally accepted methods. Sections were collected on a sliding microtome MS-3 (Russia). Staining of the obtained samples was carried out using Ehrlich hematoxylin and water-alcohol eosin. The microstructure of histologic samples was performed using Leica DM750 light microscope (Germany). Digital photography was done using ICC50 camera. 


\section{Results and discussion}

Findings showed that in the model agricultural enterprise under study, 9.5\% of the bioassays from calves contained the VD antigen. The field isolate of VD virus was assigned to a noncytopathogenic biotype according to its biological characteristics.

A study of the metabolic profile of calves infected with the agent of viral diarrhea revealed a significant change in the indices of protein, lipid, mineral metabolism and electrolyte balance (table 1).

Table 1. Biochemical blood profile of the examined calves $(\mathrm{n}=128)$

\begin{tabular}{|c|c|c|}
\hline Indices & Clinically healthy $(n=65)$ & $\begin{array}{c}\text { Infected with VD } \\
\qquad(\mathrm{n}=63)\end{array}$ \\
\hline Total protein, $\mathrm{g} / \mathrm{l}$ & $56,56 \pm 4,75^{*}$ & $49,93 \pm 3,71^{*}$ \\
\hline Albumins, $\mathrm{g} / \mathrm{l}$ & $31,18 \pm 2,11$ & $32,75 \pm 1,77$ \\
\hline Globulins, g/l & $25,38 \pm 1,85^{*}$ & $17,18 \pm 1,72 *$ \\
\hline Blood urea nitrogen, $\mathrm{mmol} / \mathrm{l}$ & $2,97 \pm 1,21 * *$ & $4,27 \pm 1,31^{* *}$ \\
\hline Cholesterol, $\mathrm{mmol} / \mathrm{l}$ & $1,73 \pm 0,72 *$ & $1,4 \pm 0,43^{*}$ \\
\hline Triglycerids, mmol/1 & $0,39 \pm 0,12 * *$ & $0,15 \pm 0,08^{* *}$ \\
\hline Total bilirubin, $\mathrm{mmol} / \mathrm{l}$ & $1,88 \pm 2,49$ & $2,62 \pm 2,70$ \\
\hline Creatinine, $\mathrm{mmol} / \mathrm{l}$ & $86,73 \pm 10,34$ & $93,98 \pm 8,30$ \\
\hline AST, u/l & $48,12 \pm 4,89$ & $50,97 \pm 3,29$ \\
\hline $\mathrm{LDH}, \mathrm{u} / 1$ & $618,47 \pm 139,61 * *$ & $1117,92 \pm 187,40^{* *}$ \\
\hline GGTP, u/l & $29,48 \pm 14,72$ & $35,6 \pm 13,02$ \\
\hline $\mathrm{AP}, \mathrm{u} / \mathrm{l}$ & $247,81 \pm 98,54 *$ & $203,44 \pm 86,40 *$ \\
\hline Creatinine kinase, $\mathrm{u} / \mathrm{l}$ & $148,34 \pm 60,50$ & $141,92 \pm 40,56$ \\
\hline Calcium, mmol/1 & $2,76 \pm 0,40^{* *}$ & $2,23 \pm 0,27 * *$ \\
\hline Phosphorus, mmol/l & $2,77 \pm 0,76$ & $2,72 \pm 0,17$ \\
\hline $\mathrm{Fe}, \mathrm{mmol} / \mathrm{l}$ & $25,18 \pm 9,70$ & $28,8 \pm 3,65$ \\
\hline $\mathrm{K}, \mathrm{mmol} / \mathrm{l}$ & $5,90 \pm 0,73 * *$ & $7,11 \pm 0,69^{* *}$ \\
\hline $\mathrm{Na}, \mathrm{mmol} / \mathrm{l}$ & $139,36 \pm 9,05$ & $135,73 \pm 8,96$ \\
\hline Chl, $\mathrm{mmol} / \mathrm{l}$ & $94,16 \pm 5,53$ & $91,17 \pm 6,68$ \\
\hline
\end{tabular}

The difference is significant if the Mann-Whitney $U$ test is applied, $\left({ }^{*}\right.$ - significant criteria at the level of $\mathrm{p}<0.05 ; * *$ - significant criteria at the level of $\mathrm{p}<0.01$ )

Infected calves revealed evidence of dysproteinemia, which is expressed in a decline in the globulin fraction. The total protein and globulin content in infected calves was on average $49.93 \pm 3.71 * \mathrm{~g} / 1$ and $17.18 \pm 1.72 * \mathrm{~g} / \mathrm{l}$, which is 10.8 and $32.3 \%$ lower than in healthy calves. The identified changes are significantly reflected in the albumin / globulin indexreaching values of $1.91 \mathrm{y} . \mathrm{e}$ in VD-infected calves.

The characteristic metabolic feature of pathological process development is the prevalence of catabolic processes, which are expressed by the accumulation of end products of nitrogen metabolism in the blood. There was a significant increase in urea to the level of 
$4.27 \pm 1.31 * * \mathrm{mmol} / \mathrm{l}$, with a insignificant rise in creatinine- $93.98 \pm 8.30 \mathrm{mmol} / \mathrm{l}$ (Table.1). It was established that calves significantly decreased lipid metabolism. So the level of cholesterol and triglycerides decreased to the minimum values-1.4 $\pm 0.43 * \mathrm{mmol} / \mathrm{l}$ and $0.15 \pm 0.08 * * \mathrm{mmol} / \mathrm{l}$, respectively.

Mineral metabolism indices in infected calves were marked by a tendency to increase the serum potassium level to the rate of $7.11 \pm 0.69 * * \mathrm{mmol} / 1$, which is $20.5 \%$ higher on average than in healthy animals. In this case, the sodium and chloride content in infected calves is insignificantly decreased and amounts to $135.73 \pm 8.96 \mathrm{mmol} / \mathrm{l}$ and $91.17 \pm 6.68 \mathrm{mmol} / \mathrm{l}$, respectively. Reduced blood total calcium is $2.23 \pm 0.27 * * \mathrm{mmol} / \mathrm{l}$, which averaged $19.0 \%$ less than in healthy animals of the same age group. Other factors of mineral metabolism disorders consist of a tendency to reduce the activity of alkaline phosphatase to the level of $203.44 \pm 86.40 * \mathrm{U} / 1$, indicating a reduction in the processes of osteosynthesis in fast-growing young animals.

We have determined that an increase in the enzyme level is a typical metabolic feature of VD in cattle. Therefore, the activity of lactate dehydrogenase in infected calves ascended by more than $80.0 \%$ and reached values of $1117.92 \pm 187.40 * *$ units/l. Evidence of hyperfermentomy of AST and GGTP were less marked, but an increase in their activity is also a metabolic sign of viral diarrhea.

A comparative review of the main hematological indicators found that healthy calves had blood values corresponding to physiological standards. A decrease in the red blood cell concentration by $11.2 \%$ was registered in infected calves. It was moderate erythrocytopenia. The level of white blood cells - by 1.8-1.9 times. The neutrophil profile of blood was insignificantly shifted "to the right". There was a trend towards a decline in the number of monocytes and eosinophils. The identified combined change in the cellular composition of the blood showed, firstly, the inhibition of hematopoiesis in calves with VD (table 2). Secondly, the deterioration of the extravascular monocyte pool. Thirdly, it pointed to a prolonged course of the infectious process in the body.

Table 2. Immunohematologic indices of clinically healthy VD infected calves

\begin{tabular}{|c|c|c|c|}
\hline \multicolumn{2}{|l|}{ Indices } & Clinically healthy $(n=65)$ & $\begin{array}{l}\text { Infected with VD } \\
(\mathrm{n}=63)\end{array}$ \\
\hline \multicolumn{2}{|c|}{ Erythrocytes, 1012/1 } & $7,23 \pm 0,40^{*}$ & $6,84 \pm 0,24 *$ \\
\hline \multicolumn{2}{|l|}{ Hemoglobin, $\mathrm{g} / \mathrm{l}$} & $104,17 \pm 10,68^{*}$ & $92,50 \pm 11,50^{*}$ \\
\hline \multicolumn{2}{|l|}{ Leukocytes, 109/1 } & $8,28 \pm 1,30^{* *}$ & $4,60 \pm 1,35^{* *}$ \\
\hline \multicolumn{2}{|c|}{ Absolute lymphocyte count, 109/1 } & $4,66 \pm 0,41^{*}$ & $2,75 \pm 0,68^{*}$ \\
\hline \multirow{7}{*}{ WBC differential } & Young, \% & $0,10 \pm 0,03$ & $0,07 \pm 0,02$ \\
\hline & Banded neutrophils, \% & $2,11 \pm 0,25$ & $0,86 \pm 0,13$ \\
\hline & $\begin{array}{l}\text { Segmentonuclear } \\
\text { neutrophils, \% }\end{array}$ & $28,05 \pm 2,10$ & $37,26 \pm 1,28$ \\
\hline & Eosinophils, \% & $5,40 \pm 0,15$ & $2,27 \pm 0,23$ \\
\hline & Monocytes, \% & $6,20 \pm 0,30$ & $3,17 \pm 0,27$ \\
\hline & Basophils, \% & $1,90 \pm 0,24$ & $0,50 \pm 0,04$ \\
\hline & Lymphocytes, $\%$ & $56,30 \pm 2,15$ & $55,87 \pm 2,37$ \\
\hline \multicolumn{2}{|l|}{ T cells, $\%$} & $38,67 \pm 1,04 *$ & $21,67 \pm 6,62 *$ \\
\hline
\end{tabular}




\begin{tabular}{|l|l|l|}
\hline T cells, 109/1 & $1,85 \pm 0,25$ & $0,62 \pm 0,28$ \\
\hline B-lymphocytes, \% & $25,78 \pm 0,42$ & $21,00 \pm 4,86$ \\
\hline B-lymphocytes, 109/л & $1,28 \pm 0,5$ & $0,60 \pm 0,27$ \\
\hline Index of T/B cells & $1,52 \pm 0,25$ & $1,04 \pm 0,27$ \\
\hline Phagocytic activity, \% & $38,17 \pm 0,67$ & $37,42 \pm 0,48$ \\
\hline Phagocytic index, RU/ml & $7,24 \pm 0,32^{*}$ & $5,39 \pm 0,87^{*}$ \\
\hline
\end{tabular}

The difference is significant if the Mann-Whitney $U$ test is applied, $(*$ - significant criteria at the level of $\mathrm{p}<0.05 ; * *$ - significant criteria at the level of $\mathrm{p}<0.01$ )

Immunologic blood tests in calves infected with VD showed a shift in the process of lymphocyte differentiation with activation of the B-cell link of immunity (table 2). Disorders in the cellular link of immunity were confirmed by a fall in the phagocytic index to $5.39 \pm 0.87 * \mathrm{RU} / \mathrm{ml}$, against $7.24 \pm 0.32 * \mathrm{RU} / \mathrm{ml}$ in healthy calves.

The diagnosed alterations were characteristic of the formation of a secondary immunodeficiency condition and confirmed the existence of a chronic viral load in calves.

During the analysis of the microstructure of histological samples of organs collected from calves infected with viral diarrhea, morphological evidence was found indicating the development of inflammatory processes in the body. Therefore, the inflammatory process in the lung tissue was characterized by a diffuse lesion of the alveoli, and a tendency to thicken their walls and hyperemia of blood vessels with active proliferation and exudation. There was evidence of bronchial catarrh, manifested by hyperplasia of the bronchial epithelium, desquamation of the epithelium, congestion of exudate in the lumen of the bronchi, and peribronchial edema. (Fig 1).

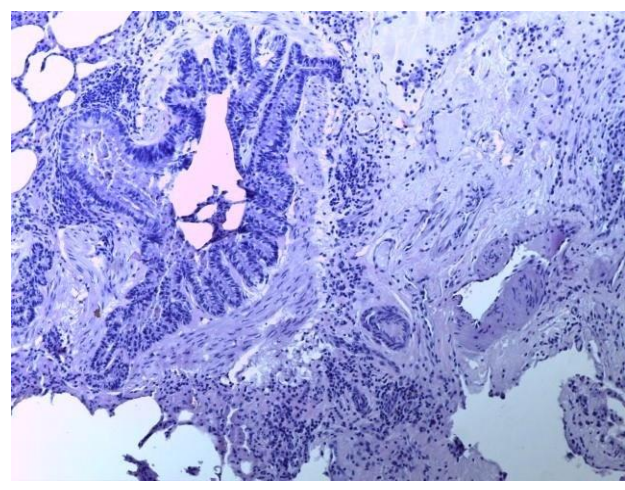

Fig.1. Bronchial catarrh and peribronchitis The lung tissue of a calf with viral diarrhea Staining with hematoxylin and eosin Magnification 100x

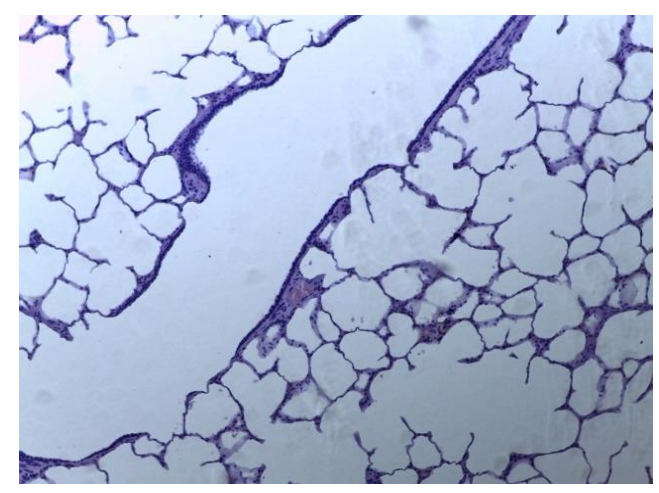

Fig.2. Compensatory emphysema of the lung tissue of a calf with viral diarrhea.

Staining with hematoxylin and eosin Magnification 200x

In a variety of cases, histological examination of lung tissue detected edema of the surrounding bronchial tissue. Congestion of white blood cells was observed in the lumen of capillaries and small bronchi, which is specific for purulent bronchitis. There was an overgrowth of peribronchial connective tissue and, consequently, compensatory emphysema development. (Fig. 2).

During speen examination, it was determined that the follicles are sharply decreased in volume and have a weakly defined contour of lymphoid cells surrounding the central arteries. 
Decrease of most of the lymphoid follicles is a pathognomonic evidence of congenital immunodeficiency in calves. The presence of a significant amount of the pigment hemosiderin in the spleen tissues was observed, indicating the previous hemorrhagic infiltration of the red pulp of the spleen and the utilization of red blood cells (Fig. 3).

Evidence of serous lymphadenitis were recorded in the lymph nodes on the background of reduction of subcapsular lymphoid follicles, both in the subcapsular and central sinuses with simultaneous growth of connective tissue in the organ stroma (Fig. 4).

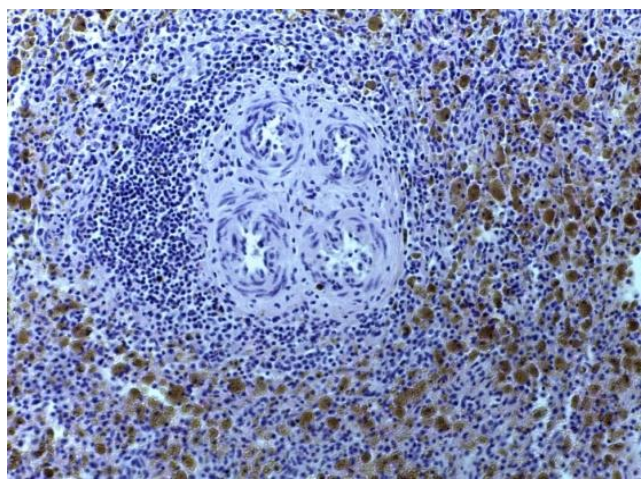

Fig.3. Reduction of lymphoid follicles of the calf spleen with viral diarrhea.

Staining with hematoxylin and eosin.

Magnification 100x

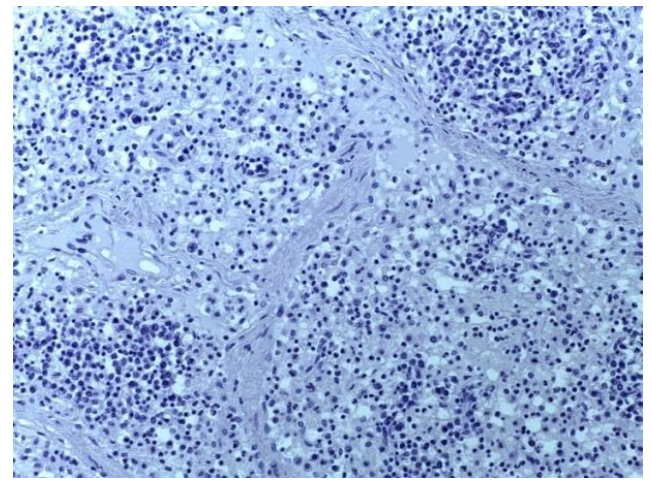

Fig.4. Serous lymphadenitis

Connective tissue overgrowth in the central sinus. Calf lymph node with viral diarrhea. Staining with hematoxylin and eosin. Magnification 100x

Morphological evidence revealed in the liver and kidney tissues pointed to non-specific disorders in the organs, indicating the initial stages of dystrophic and inflammatory processes. For example, granular dystrophy of hepatocytes, micronecrosis, and activation of stellate reticuloendotheliocytes were found in liver tissues. Evidence of granular dystrophy of nephrocytes and micronecrosis of the epithelium of convoluted tubules of the 1st order was detected in kidney tissues. For some cases, compensatory sclerotic process was found.

\section{Conclusion}

The metabolic profile of calves infected with the agent of viral diarrhea is characterized by a significant alter in the indicators of protein, lipid, mineral metabolism and electrolyte balance and developing dysproteinemia. Immunologic examinations of the blood of infected calves revealed a shift in the process of lymphocyte differentiation with activation of the b-cell link of immunity and a reduction in the phagocytic index to $5.39 \pm 0.87 * \mathrm{RU} / \mathrm{ml}$, against $7.24 \pm 0.32 *$ $\mathrm{RU} / \mathrm{ml}$ in healthy calves. Therefore, VD-infected calves form an immunosuppressive condition with a predominance of structural immunodeficiency. Pathognomonic morphological feature of immunodeficiency is the decline of most of the lymphoid follicles and the presence of a significant amount of hemosiderin pigment in the spleen tissues. Other signs include decrease of subcapsular lymphoid follicles; development of serous lymphadenitis in the subcapsular and central sinuses with simultaneous growth of connective tissue in the organ stroma. Inflammatory processes developing in the lung tissue in the form of catarrhal and purulent bronchitis are also typical morphological features indicating infection of VD in calves. 


\section{References}

1. A.E. Verkhovskaya, V.A. Sergeyev, T.I. Aliper. Veterinariya, 8, 3 - 7 (2009) (In Russian)

2. A.G. Glotov, T.I. Glotova. Veterinariya, 4, 3-8 (2015) (In Russian).

3. A.G. Glotov, T.I. Glotova. Veterinariya, 6, 3-11 (2019) (In Russian).

4. I.A. Shkuratova. Integrated program of biological protection and rehabilitation of agricultural enterprises from bovine viral diarrhea. (Research and methodological recommendations, Ural publishing house, Yekaterinburg, 2019) (In Russian).

5. O.G. Petrova, M.I. Barashkin. Agrarian Bulletin of the Urals, 6(124), 40-42 (2014) (In Russian).

6. A.V. Pchel'nikov, Etiology, age and seasonal dynamics of viral respiratory diseases in calves in breeding farms. (Dissertation of the Candidate of Veterinary Sciences (PhD), Moscow, 2018) (In Russian).

7. O.V.Sergeyev. Veterinariya Kubani, 5, 23 - 26 (2009) (In Russian).

8. P.N. Smirnov, N.V. Efanova. Panel of the most informative tests for evaluating animal resistance. (Novosibirsk state agrarian University. Russian agricultural academy. Siberian branch, Novosibirsk, 2007) (In Russian).

9. E.N. Shilova, M.V. Ryaposova, I.V. Shkuratova, I.V. Vyalykh. Veterinariya, 5, 19-21 (2014) (In Russian).

10. C.L. Kelling. Vet. Clin. Food Anim, 20, 115-129 (2004)

11. K. Stahl. Jap. J. of Vet. Res, 60, 31-39 (2012) 